\title{
Cost-Optimal Plus Energy Building in a Cold Climate
}

\section{Szymon Firlagg}

The Faculty of Civil Engineering, Warsaw University of Technology, Aleja Armii Ludowej 16, 00-637 Warsaw, Poland; s.firlag@il.pw.edu.pl; Tel.: +48-605-784-134

Received: 3 September 2019; Accepted: 8 October 2019; Published: 11 October 2019

\begin{abstract}
The main objective of this article is to propose possible requirements for cost-optimal plus energy building in a cold, heating dominated climate. The open question is what is more cost-effective: reduction of energy demand or increase of production from renewable energy sources. The target of the research was to check which solution has the lowest investment and maintenance costs. The analysis was made for a single-family house located in central Poland, including three different energy standards: WT2021 with energy need for heating $\leq 100 \mathrm{kWh} /\left(\mathrm{m}^{2}\right.$ year $)$, NF40 with energy need for heating $\leq 40 \mathrm{kWh} /\left(\mathrm{m}^{2}\right.$ year) and NF15 with energy need for heating $\leq 15 \mathrm{kWh} /\left(\mathrm{m}^{2}\right.$ year $)$ ). Air and ground source heat pumps were used as a heat source and a photovoltaic system for the production of the electrical energy. For each case the investment and running costs were calculated very precisely, taking into account heating, ventilation, domestic hot water and auxiliary systems. Global cost for a 30-year period showed that house variants with air source heat pumps are more cost effective. The investment, replacement and maintenance cost related with energy systems have the biggest share in the global cost. Reaching the plus energy standard was possible only in the case of low-energy standard NF40 and NF15. Based on this research the proposed requirements for plus energy single-family residential buildings in central Poland are the following: the final (delivered) electrical energy demand (including heating, ventilation, domestic hot water and auxiliary systems) $<45 \mathrm{kWh} /\left(\mathrm{m}^{2}\right.$ year $)$ and the on-site electrical energy production $>45 \mathrm{kWh} /\left(\mathrm{m}^{2}\right.$ year $)$.
\end{abstract}

Keywords: plus energy; cost-optimal; single family house; renewable energy sources; heat pump

\section{Introduction}

The Energy Performance of Buildings Directive (EPBD) [1] requires that all new buildings constructed in the European Union (EU) from 2021 (in the case of public utility buildings from 2019) are buildings with nearly zero energy consumption (NZEB). According to the revised EPBD [2] by 2050 we should decarbonise the building stock, which is currently responsible for about $36 \%$ of all $\mathrm{CO}_{2}$ emissions in the EU. The Member States, including Poland, have set out the country requirements for standard NZEB [3]. These requirements include, among others, thermal insulation of buildings elements and maximum non-renewable primary energy consumption (in Poland only the part of the energy that is coming from fossil fuels is included in the calculations). Abundant research indicates how to optimize single-family residential buildings to meet the requirements $[4,5]$ or how to renovate to NZEB standard [6,7]. Reaching the aforementioned European goals, related to the building stock by 2050, can be complicated without more ambitious solutions. Meanwhile, new research show that the future will belong to plus energy buildings. The study of Gustafsson [8] concentrates on building energy systems in the context of renovation. This is especially important when aiming towards the $100 \%$ share of the renewable system in the future. To reach the plus energy standard a combination of photovoltaics, heat pumps, balanced ventilation with heat recovery and improved building envelopes is needed [9]. Therefore, a whole design process is to be optimized from the architectural and economic perspective [10]. One of the solutions can be the use of building integrated photovoltaics [11]. Examples 
of already-built plus energy houses can be found e.g., in Germany [12] where the Federal Ministry of the Interior for Building and Homeland is already promoting such a standard.

The question is how feasible requirements for the plus energy building definition should be formulated in central Poland. In order to find an answer, various energy efficiency standards of the model house were analysed, including different types of heat pumps, photovoltaic and ventilation systems. For each variant the global cost was calculated over a 30-year period. The used calculation period was based on the methodology framework established by the Commission with the Delegated Act No. 244/2012. According to the regulation for residential and public buildings 30 years of calculation period should be taken into account, and for commercial, non-residential buildings at least 20 years. The minimal cost was used as an optimizing criterion. The general definition states that building is plus energy when it produces more energy from renewable energy sources, over the course of a year, than it needs for heating, ventilation, domestic hot water (DHW) and auxiliary systems [13]. According to the concept [13] generated electricity, which is not consumed in place, is sent to the electricity grid. The power grid plays the role of energy storage in such a solution. Additionally, reaching of plus energy standard is only possible for buildings with a very high energy efficiency level, what confirms the study of Melgar, Bohórquez and Márquez [14]. What precise solutions in terms of construction and systems should be used are not always clear. Taking in consideration that the aim of the research was to check what is more cost-effective; the reduction of energy demand (e.g., thanks to better insulation of building elements) or the increase of production from renewable energy sources. At one point there has to be an optimum combination of those two measures, in combination with the minimal global cost. Research results were used to define possible requirements for plus energy building in the cold climate of central Poland.

The capital Warsaw was chosen as the location of the building, representing an average climate of central Poland. The city has a humid continental climate with long cold winters and short warm summers. The average length of the heating season is 222 days with the average outdoor air temperature of $3.4^{\circ} \mathrm{C}$. Yearly in-plane irradiation is $1100 \mathrm{kWh} / \mathrm{m}^{2}$ [15]. For the determination of the plus energy standard a single-family building model was used. It well represents typical new single-family buildings constructed in Poland and does not include any special solutions referring to its construction or architecture.

The whole paper has following structure:

- materials and method-description of the calculation methodology, used building model and analysed variants,

- $\quad$ systems dimensioning—selection of air and ground source heat pumps for different building variants, selection of photovoltaic panels on a basis of total final energy consumption for heating, hot water and auxiliary systems,

- cost calculation-calculations of investment costs including construction and systems, calculation of annual costs related to energy consumption, systems replacement and maintenance,

- results and discussion-global cost comparison and selection of cost-optimal variant,

- conclusions-proposition of requirements for plus energy single-family residential buildings in central Poland.

\section{Material and Method}

\subsection{Calculation Methodology}

The process of determining requirements for the plus energy building definition was divided into the following stages:

- calculation of energy performance of the house,

- systems dimensioning,

- global cost calculation. 
The first stage was defining the energy performance of a single-family house used as the model building. The calculations were made for three different energy efficiency standards. Energy data were the basis for the dimensioning of building systems. Adequate heat pumps, PV systems and balanced ventilation were selected. Based on them it was possible to determine six main variants of plus energy house using either an air or ground source heat pump.

The aim of the global cost calculation was to determine the cost-optimal variant. The results depended on the energy efficiency standard and energy systems in the building. As an optimizing criterion, the minimal global cost (including investment + running costs) was used, calculated over a 30-year period. The calculations were based on the standard EN 15459-1 Energy performance of buildings, Economic evaluation procedure for energy systems in buildings, Part 1: Calculation procedures [16] and literature review [17,18]. The global cost for the 30-year period for the purpose of the study was calculated on basis of the following formula:

$$
C_{G}=C_{I}+\sum_{i=1}^{30}\left(C_{a}(i) \cdot f_{p v}(i)\right)-\sum_{j=1} V_{30 \_f}(j),
$$

where:

- $\quad C_{I}$-initial investment cost including additional constructions and systems costs, EUR;

- $\quad C_{a}(i)$-annual costs of the year $i$ represent the sum of maintenance costs and energy costs or replacement costs paid in the year $i$, EUR;

- $f_{p v}(i)$ - present value factor;

- $\quad V_{30 \_f(j)}$-final value of the component $j$ at the end of the calculation period, EUR.

The present value factor is the factor by which any annual costs are to be multiplied in order to be comparable with the initial investment at the time of installation. It was calculated for the year $i$ with the use of the following formula:

$$
f_{p v}(i)=\frac{(1+s)^{i} \cdot(1+e)^{i}}{(1+d)^{i}}
$$

where:

- $s$-annual inflation rate;

- $d$-discount rate;

- $e-$ evolution of energy prices (electrical energy) over the inflation rate in the analysed period.

The annual costs of the year $i$ represent the sum of energy consumption, systems maintenance and replacement costs paid in specific years. It was calculated with the use of the following formula:

$$
C_{a}(i)=C_{R j, T n}+C_{e}+C_{m}
$$

where:

- $\quad C_{R j, T n}$-replacement costs for component or system $j$ at time $T_{n}$ and $2 T_{n}$ if the calculation period is longer or equal to $2 T_{n}$;

- $\quad T_{n}$-lifetime expectancy for a component $j$ (or system) normally specified in years;

- $C_{e}$-cost of energy consumption for heating, ventilation, DHW and auxiliary systems;

- $C_{m}$-maintenance costs.

The final value of the component $j\left(V_{30} f(j)\right)$ at the end of the calculation period was calculated if its lifespan was longer than the calculation period of 30 years. For example, if the component had to be replaced in year 30 the full replacement cost was multiplied by present value factor and subtracted from the annual costs. But if the lifespan of the component was 15 years and it was replaced for the first time in year 15 the final value of the component at the end of the calculation period will be 0 (zero). 


\subsection{Building Variants}

The calculations were made for three different building energy efficiency standards referring to envelope performance, ventilation system and energy demand:

- WT2021-This is the term for the requirements for new buildings designed according to the building code [3] that will be built in Poland from 2021. The requirements apply to the maximum heat transfer coefficients (U-values) of building elements and the coefficient of maximum annual demand for non-renewable primary energy $\left(\mathrm{Q}_{\mathrm{P}}\right)$ for heating, ventilation, cooling, domestic hot water preparation and lighting. From 2021, it will be reduced to a maximum of $70 \mathrm{kWh} /\left(\mathrm{m}^{2}\right.$ year).

- NF40-This is the term for a low-energy house, characterized by the energy need for heating $\left(\mathrm{Q}_{\mathrm{H}}\right)$ no higher than $40 \mathrm{kWh} /\left(\mathrm{m}^{2}\right.$ year). The standard was defined by the National Fund for Environmental Protection and Water Management (NFEP and WM) in Poland as part of a program supporting the energy-efficient buildings [19]. The energy demand for heating of new houses is typically about $100 \mathrm{kWh} /\left(\mathrm{m}^{2}\right.$ year $)$.

- $\quad$ NF15-This is the term for a passive house, characterized by the energy need for heating $\left(\mathrm{Q}_{\mathrm{H}}\right)$ no higher than $15 \mathrm{kWh} /\left(\mathrm{m}^{2}\right.$ year). The standard was also defined by the NFEP and WM [19]. To achieve such a low energy demand, the building must be properly designed, constructed and equipped with very efficient ventilation system.

It is worth noting that the WT2021 concentrates on demand for non-renewable primary energy while NF40 and NF15 on energy demand for heating. Specific requirements for the given standards are shown later in the paper. In order to reach plus energy level systems, components have to be used which reduce the house final energy consumption and maximize renewable energy production on the site. In the scope of the research the following systems were included:

- PV—Photovoltaic solar panels were used to produce electrical energy. Depending on the situation monocrystalline or polycrystalline solar panels were applied. The surface of the roof of the house on which the panels can be installed is usually limited, e.g., to $35 \mathrm{~m}^{2}$ in the case of the used model house.

- ASHP-Air source heat pump using energy stored in ambient air. Split system consists of one unit inside and one outside the building. The heat is distributed through the surface, water central heating system and used for the heating of DHW. The ASHP type has to be appropriate to work in cold climate. The key element of such a construction is the electronically controlled compressor with EVI (enhanced vapour injection) technology [20].

- GSHP-Ground source heat pump with vertical exchanger using energy accumulated in the ground for heating and domestic hot water preparation. The pipes run in vertical holes bored in the ground with a diameter of 10-15 cm deep at 15-200 $\mathrm{m}$. The minimum distance between holes is 5 to $6 \mathrm{~m}$ [21,22]. Stable ground temperature at a lower depth allows for higher efficiency of the heat pump, shorter loops reduce pumping costs and the exchanger takes up less space.

The house model has been subjected to six variants differing in the energy efficiency standards and the systems. In order to reduce the energy needs for heating balanced ventilation with heat recovery was introduced in the NF40 and NF15 standards. All the variants are presented in Table 1.

Table 1. Analysed variants matrix.

\begin{tabular}{|c|c|c|}
\hline Energy Efficiency Standard & Systems & Ventilation Type \\
\hline WT2021 & $\begin{array}{l}\mathrm{ASHP}+\mathrm{PV} \\
\mathrm{GSHP}+\mathrm{PV}\end{array}$ & Natural ventilation \\
\hline NF40 & $\begin{array}{l}\mathrm{ASHP}+\mathrm{PV} \\
\mathrm{GSHP}+\mathrm{PV}\end{array}$ & Balanced ventilation with heat recovery \\
\hline NF15 & $\begin{array}{l}\text { ASHP + PV } \\
\text { GSHP + PV }\end{array}$ & Balanced ventilation with heat recovery \\
\hline
\end{tabular}


The research included two different heat pump types in order to check how they influenced the results. Currently in Poland air source heat pumps are becoming very popular because they are cheaper than pumps with a ground exchanger [23]. Unfortunately, their energy efficiency is lower compared to ground source heat pumps [24], what is especially important in a cold climate of Poland. One of the research tasks was to check if the investment in higher efficiency is cost effective in the case of plus energy buildings.

\subsection{Building Model and Energy Performance}

A single-family building model was used to determine the requirements for plus energy standard (Figure 1). It was a two-storey, detached house without basement, with a heated, usable attic. The building has compact shape, designed on a rectangular plan. It has traditional brick construction. The heated attic was covered with a gable roof with a wooden structure. The visible lucarne was oriented towards the south. The area of the roof, oriented on the south, on which the PV panels could be installed, was limited to $35 \mathrm{~m}^{2}$. The basic geometric data of the house are shown in Table 2. The used model well represents typical new single-family buildings constructed in Poland.

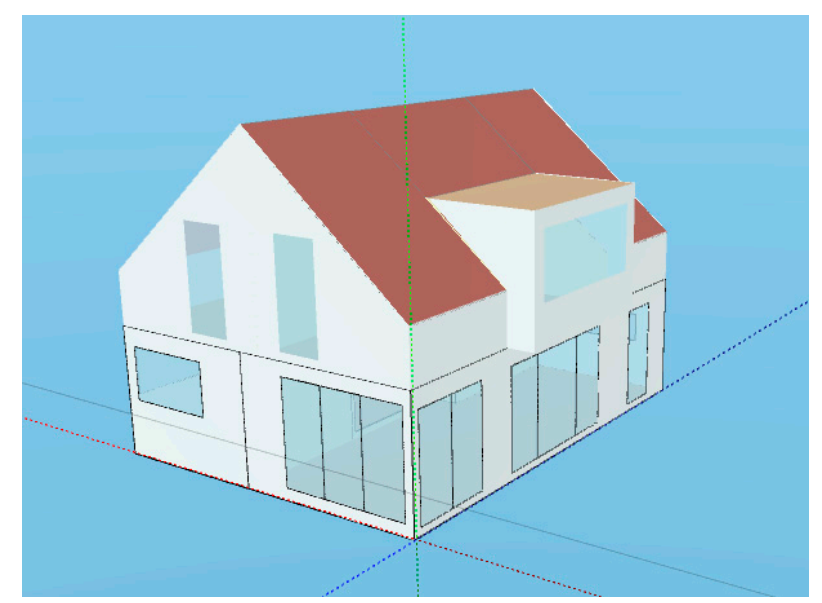

Figure 1. An axonometric projection of the building from the south-western side in the Audytor OZC software [25].

Table 2. Basic geometric data.

\begin{tabular}{ccc}
\hline Parameter & Value & Units \\
\hline Heated area & 129.0 & $\mathrm{~m}^{2}$ \\
Heated volume & 307.1 & $\mathrm{~m}^{3}$ \\
Gross covered area & 91.5 & $\mathrm{~m}^{2}$ \\
Shape factor & 0.67 & $\mathrm{~m}^{-1}$ \\
\hline
\end{tabular}

The 3D model of the house and the energy performance was created in software Audytor OZC (energy need calculation) version 6.8 Pro (Sankom, Warsaw, Poland). The axonometric projections can be seen in Figure 2. 


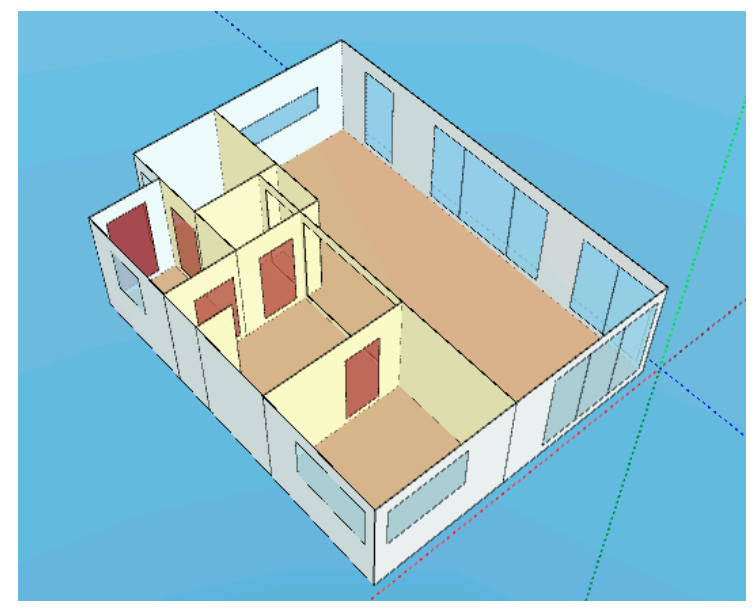

(a)

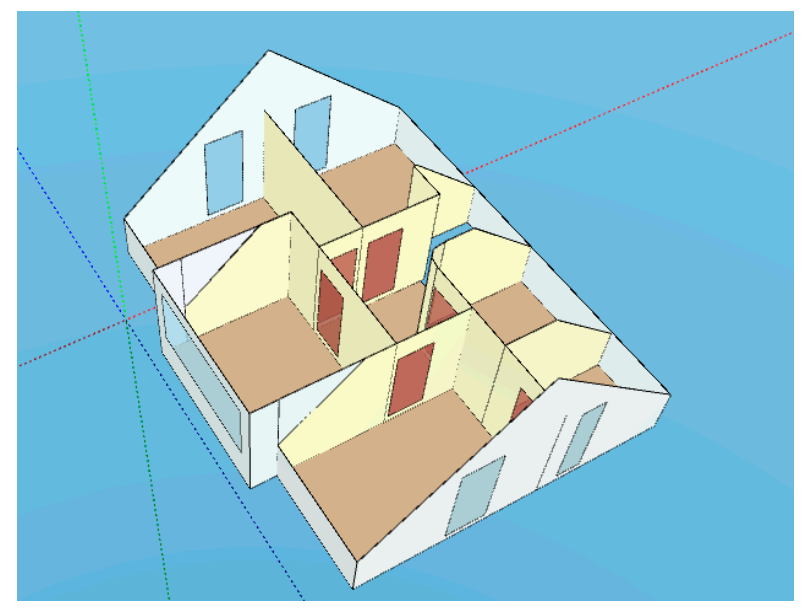

(b)

Figure 2. An axonometric projection of the building consignations: (a) ground floor; and (b) attic in the Audytor OZC software [25].

The precise requirements for individual energy efficiency standard are shown in Tables 3 and 4. The comparison concerns the maximum values of heat transfer coefficients (U-value) and linear heat loss coefficients ( $\Psi$-value), ventilation type and efficiency, air-tightness and energy demand.

Table 3. Heat transfer coefficient (U-value) requirements for the WT2021, NF40 and NF15 standards $[3,19]$.

\begin{tabular}{ccccc}
\hline Units & Maximum U-values of Building Elements & WT2021 & NF40 & NF15 \\
\hline & External walls & 0.20 & 0.15 & 0.10 \\
& Roofs, flat roofs and floors under unheated attics & 0.15 & 0.12 & 0.10 \\
$\mathrm{~W} /\left(\mathrm{m}^{2} \mathrm{~K}\right)$ & Floors over unheated basements and closed spaces, floors on the ground & 0.30 & 0.20 & 0.12 \\
& External and garage doors & 1.3 & 1.3 & 0.8 \\
& Windows, balcony doors and transparent facades & 0.90 & 1.0 & 0.8 \\
\hline
\end{tabular}

Table 4. A list of linear heat loss coefficients ( $\Psi$-value) and system requirements for the WT2021, NF40 and NF15 standards [3,19].

\begin{tabular}{|c|c|c|c|c|}
\hline Units & Requirement & WT2021 & NF40 & NF15 \\
\hline \multicolumn{5}{|c|}{ Maximum $\Psi$-values of thermal bridges } \\
\hline \multirow{2}{*}{$\mathrm{W} /(\mathrm{m} \mathrm{K})$} & Balconies & around 0.70 & 0.20 & 0.01 \\
\hline & $\begin{array}{c}\text { Others places, e.g., window } \\
\text { opening }\end{array}$ & around 0.70 & 0.10 & 0.01 \\
\hline$\%$ & Ventilation type and efficiency & $\begin{array}{l}\text { natural, } \\
\text { no requirements }\end{array}$ & $\begin{array}{l}\text { balanced ventilation } \\
\text { with heat recovery, } \\
\geq 85\end{array}$ & $\begin{array}{c}\text { balanced ventilation } \\
\text { with heat recovery, } \\
\geq 90\end{array}$ \\
\hline $1 / \mathrm{h}$ & Envelope air-tightness in $n_{50}$ & 3.0 & 1.0 & 0.6 \\
\hline $\mathrm{kWh} /\left(\mathrm{m}^{2}\right.$ year $)$ & $\begin{array}{c}\text { Non-renewable primary } \\
\text { energy demand }\end{array}$ & $\mathrm{Q}_{\mathrm{P}} \leq 70$ & no & no \\
\hline $\mathrm{kWh} /\left(\mathrm{m}^{2}\right.$ year $)$ & Energy need for heating & no & $\mathrm{Q}_{\mathrm{H}} \leq 40$ & $\mathrm{Q}_{\mathrm{H}} \leq 15$ \\
\hline
\end{tabular}

For each variant the energy need for heating was calculated with use of software Audytor OZC in accordance with ISO 13790 standard [26]. The Audytor OZC software is used to assist in the calculation of the design heating load of rooms and buildings, determination of the seasonal energy need for heating and cooling and performance of Energy Certificates for buildings and their parts. The program can also carry out moisture analysis of building elements. Design heating load was calculated in accordance with EN 12831-1 standard [27] and used for the systems dimensioning. It was assumed that the house is located in Warsaw representing a typical Polish climate. The number of heating degree days (HDD) for Warsaw is $3686 \mathrm{Kd}$. The energy need for hot water heating was calculated on basis 
of Polish regulation [28]. All the assumptions used for the calculations were summarized in Table 5. The energy needs for heating and DHW preparation is given in Table 6.

Table 5. Assumptions used for the energy need and design heating load calculation for the WT2021, NF40 and NF15 standards.

\begin{tabular}{ccc}
\hline Assumption & Value & Units \\
\hline Design outdoor air temperature & -20.0 & ${ }^{\circ} \mathrm{C}$ \\
Average yearly outdoor air temperature & 7.6 & ${ }^{\circ} \mathrm{C}$ \\
Design indoor air temperature-rooms & 20.0 & ${ }^{\circ} \mathrm{C}$ \\
Design indoor air temperature-bathrooms & 24.0 & ${ }^{\circ} \mathrm{C}$ \\
Design hot water temperature & 55.0 & ${ }^{\circ} \mathrm{C}$ \\
Design hot water consumption & 180.0 & $1 /$ day \\
Air exchange rate & 0.60 & $\mathrm{H}^{-1}$ \\
\hline
\end{tabular}

Table 6. Energy need for heating and DHW preparation for the WT2021, NF40 and NF15 standards.

\begin{tabular}{cccc}
\hline \multirow{2}{*}{$\begin{array}{c}\text { Energy Efficiency } \\
\text { Standard }\end{array}$} & $\begin{array}{c}\text { Energy Need for } \\
\text { Heating, } \mathbf{Q}_{\mathbf{H}}\end{array}$ & $\begin{array}{c}\text { Energy Need for DHW } \\
\text { Preparation, } \mathbf{Q}_{\mathrm{DHW}}\end{array}$ & Design Heating Load, $\boldsymbol{\Phi}$ \\
\cline { 2 - 4 } & $\mathbf{k W h} / \mathbf{( m}^{2}$ year $)$ & $\mathbf{k W h} /\left(\mathbf{m}^{2}\right.$ year $)$ & $\mathbf{k W}$ \\
\hline WT2021 & 99.4 & & 8.7 \\
NF40 & 35.1 & 25.0 & 4.6 \\
NF15 & 11.8 & & 3.1 \\
\hline
\end{tabular}

Change of envelope and ventilation system parameters had visible influence on energy performance. Energy need for heating and design heating load decreased with the increase of requirements. The energy need for DHW preparation was the same for all standards. In all the energy efficiency standards the parameters of inside comfort were at the same level as shown in Table 5.

\section{Systems Dimensioning}

In order to reach the plus energy level it was necessary to properly select the buildings systems for each variant. As part of the work, heat pumps, PV panels and ventilation with heat recovery were selected. Selection of exact model made it possible to precisely determine the price and efficiency of the devices.

\subsection{Heat Pumps Selection}

Two types of heat pumps were chosen for each energy efficiency standard of the house-ASHP or GSHP. The ground source heat pump works with a vertical exchanger. To make the comparison more reliable (to eliminate the influence of the brand) only one supplier was selected namely the company NIBE. The design heating load of the house included the transmission and ventilation losses and was calculated in accordance with EN 12831-1 standard [27]. On the basis of the results obtained, heat pumps were selected together with all the fittings necessary for the proper functioning of the entire system. The heating capacity of the heat pumps was always higher than the design heating load. From the manufacturer's catalogue the first device in the order was always chosen with the capacity higher than the designed one. It was assumed that heat pumps will work with low temperature $\left(35^{\circ} \mathrm{C}\right.$ - design supply temperature), under floor, water heating.

Using the NIBE catalogue, the Standard 12 Monoblok and Standard 6 Monoblok air source heat pumps were chosen. They are designed for central and water heating, even by an outdoor temperature of $-20^{\circ} \mathrm{C}$. The set included: heat pump F2040 $12 \mathrm{~kW}$ or $6 \mathrm{~kW}$, internal unit HK $200 \mathrm{M}$ with hot water heater of a $180 \mathrm{~L}$ capacity, heat exchanger and control module SMO 20. Table 7 shows the basic parameters of the pump. 
Table 7. Basic technical parameters of the air source heat pump (ASHP) selected for the WT2021, NF40 and NF15 standards [29].

\begin{tabular}{ccc}
\hline \multirow{2}{*}{ Technical Parameter } & \multicolumn{2}{c}{ Energy Efficiency Standard } \\
\cline { 2 - 3 } & WT2021 & NF40 and NF15 \\
\hline Heat pump model & F2040 $12 \mathrm{~kW}$ & $\mathrm{~F} 20406 \mathrm{~kW}$ \\
Heating capacity range & $3.5-12 \mathrm{~kW}$ & $2.0-6 \mathrm{~kW}$ \\
Electric power & $1.79 \mathrm{~kW}$ & $0.55 \mathrm{~kW}$ \\
Nominal heating capacity & $6.91 \mathrm{~kW}$ & $2.32 \mathrm{~kW}$ \\
Seasonal space heating energy efficiency, cold climate, $35{ }^{\circ} \mathrm{C}$ & $142 \%$ & $134 \%$ \\
Water heating energy efficiency, cold climate & $88 \%$ & $89 \%$ \\
Min. working temperature & $-20{ }^{\circ} \mathrm{C}$ & $-20{ }^{\circ} \mathrm{C}$ \\
Max. DHW temperature & $58{ }^{\circ} \mathrm{C}$ & $58{ }^{\circ} \mathrm{C}$ \\
Sound pressure level & $43 \mathrm{~dB}$ & $35 \mathrm{~dB}$ \\
\hline
\end{tabular}

In all cases the heating capacity of the ASHP was higher than the designing heating load. In the case of NF15 it was even twice higher because the F2040 $6 \mathrm{~kW}$ was the smallest device produced by the company. During the research process a lot of effort was made to find a suitable heat pump (with very low heating capacity) for NF15 standard. For example, Samsung offers a heat pump EHS SPLIT $4.4 \mathrm{~kW}$ but it is only for heating and not for hot water preparation. Daikin offers Altherma III Bluevolution with $4.3 \mathrm{~kW}$ but it is only suitable for average climate and not for cold climate conditions. A suitable heat pump e.g., iTec from Thermia has a capacity of $5.0 \mathrm{~kW}$ so is very similar to the selected type. The additional capacity was used for DHW heating which especially important during the cold winters.

According to the literature [30] the influence of over-sizing on the energy efficiency of the heat pump is smaller than influence of under-sizing in the cold climate. By over-sizing the heat pumps work more often in the on-off mode. As a result the efficiency decreases by $3 \%-6 \%$. By under-sizing the heat pumps, they work more often with full speed of the compressor and the amount of energy consumed by the auxiliary electric heater increases. As a result the efficiency decreases by $3 \%-18 \%$. For the ground source heat pump the dual-function NIBE F1226 device was chosen with heating capacity $12 \mathrm{~kW}$ or $6 \mathrm{~kW}$. The pumps have integrated hot water heater of $180 \mathrm{~L}$ capacity. Table 8 shows the basic parameters of the devices.

Table 8. Basic technical parameters of the ground source heat pump (GSHP) selected for the WT2021, NF40 and NF15 standards [31].

\begin{tabular}{ccc}
\hline Technical Parameter & \multicolumn{2}{c}{ Energy Efficiency Standard } \\
\cline { 2 - 3 } & WT2021 & NF40 and NF15 \\
\hline Heat pump model & $\mathrm{F} 122612 \mathrm{~kW}$ & $\mathrm{~F} 12266 \mathrm{~kW}$ \\
Electric power & $2.68 \mathrm{~kW}$ & $1.31 \mathrm{~kW}$ \\
Nominal heating capacity & $11.52 \mathrm{~kW}$ & $5.49 \mathrm{~kW}$ \\
Seasonal space heating energy efficiency, cold climate, $35{ }^{\circ} \mathrm{C}$ & $177 \%$ & $170 \%$ \\
Water heating energy efficiency, cold climate & $89 \%$ & $91 \%$ \\
Max. DHW temperature & $63{ }^{\circ} \mathrm{C}$ & $63{ }^{\circ} \mathrm{C}$ \\
Sound pressure level & $29 \mathrm{~dB}$ & $28 \mathrm{~dB}$ \\
\hline
\end{tabular}

In all cases the heating capacity of the GSHP was higher than the designing heating load. In case of NF15 it was even twice higher because the F2040 $6 \mathrm{~kW}$ was the smallest device produced by the company. In regard to the ASHP seasonal space heating energy efficiency was visibly higher but the water heating energy efficiency was very similar. The technical parameters of the heat pumps were the basis for the calculation of annual final energy demand. 


\subsection{Photovoltaic Panels Selection}

In order to properly select the peak power of the PV system it was necessary to calculate the annual final energy demand of the house and compare it with electrical energy production of the system. In order to reach the plus energy level, the final, annual energy consumption for heating, ventilation, domestic hot water and auxiliary systems should be smaller than the annual production of the PV system. The annual energy consumption in $\mathrm{kWh}$ in terms of final energy should be calculated as the ratio of the reference annual heating or DHW need and the total, seasonal space heating or water heating energy efficiency. The energy efficiency of building systems was evaluated based on supplier data $[29,31]$, the Polish regulation [28] and several European reference standards: EN 15243 [32], EN 15316 [33] and EN 15316-3-1:2005 [34]. Seasonal space and water heating energy efficiency of the heat pumps was calculated on basis of data from Tables 7 and 8 multiplied by the primary energy factor for electrical energy equal to 2.5 according the Regulation No 811/2013 [35]. The total efficiency for both heat pumps is presented in Tables 9 and 10. The total efficiency of the heating system was calculated on basis of the following formula:

$$
\eta_{H, t o t}=\eta_{H, g} \times \eta_{H, e} \times \eta_{H, d} \times \eta_{H, s}
$$

where:

- $\quad \eta_{H, g}$ - seasonal space heating energy efficiency;

- $\eta_{H, e}$-seasonal control and heat use energy efficiency;

- $\eta_{H, d}$-seasonal heat distribution energy efficiency;

- $\eta_{H, s}$-seasonal heat storage energy efficiency.

Table 9. Calculation of total energy efficiency of floor and DHW heating systems with ASHP.

\begin{tabular}{cccc}
\hline System Type & Seasonal Energy Efficiency & WT2021 & NF40 and NF15 \\
\hline \multirow{3}{*}{ Floor heating } & heat pump & 3.55 & 3.35 \\
& $\begin{array}{c}\text { control and heat use } \\
\text { heat distribution } \\
\text { heat storage }\end{array}$ & \multicolumn{2}{c}{0.89} \\
& total, seasonal & 2.86 & 0.95 \\
& heat pump & 2.20 & \multicolumn{2}{c}{2.72} \\
\hline DHW use & \multicolumn{2}{c}{1.0} \\
DHW heating & DHW distribution & \multicolumn{2}{c}{0.60} \\
& DHW storage & 1.12 & 0.85 \\
& total, seasonal & \multicolumn{2}{c}{1.13} \\
\hline
\end{tabular}

Table 10. Calculation of total energy efficiency of floor and DHW heating systems with GSHP.

\begin{tabular}{cccc}
\hline System Type & Seasonal Energy Efficiency & WT2021 & NF40 and NF15 \\
\hline \multirow{3}{*}{ hloor heating } & heat pump & 4.43 & \multicolumn{2}{c}{4.25} \\
& control and heat use & \multicolumn{2}{c}{0.89} \\
heat distribution & \multicolumn{2}{c}{0.96} \\
heat storage & \multirow{2}{*}{0.95} \\
total, seasonal & 3.59 & \multicolumn{2}{c}{3.45} \\
\hline \multirow{3}{*}{ DHW heating } & heat pump & 2.23 & \multicolumn{2}{c}{2.28} \\
& DHW use & \multicolumn{2}{c}{0.0} \\
& DHW distribution & \multicolumn{2}{c}{0.60} \\
& DHW storage & \multirow{2}{*}{1.12} & \multicolumn{2}{c}{1.13} \\
\hline
\end{tabular}


The total efficiency of the hot water system was calculated on the basis of the following formula:

$$
\eta_{W, t o t}=\eta_{W, g} \times \eta_{W, e} \times \eta_{W, d} \times \eta_{W, s,}
$$

where:

- $\quad \eta_{W, g}$-seasonal water heating energy efficiency;

- $\quad \eta_{W, e}$-seasonal efficiency of water use;

- $\eta_{W, d}$-seasonal hot water distribution energy efficiency;

- $\eta_{W, s}-$ seasonal hot water storage energy efficiency.

The next stage was the calculation of annual, final energy consumption for all standards and systems. The consumption included heating, DHW and electrical energy used by auxiliary systems-control, pumps and ventilation unit (only in case of NF40 and NF15). Results are shown in Table 11.

Table 11. Final energy consumption for heating, DHW and auxiliary systems for the WT2021, NF40 and NF15 standards.

\begin{tabular}{|c|c|c|c|c|c|c|}
\hline \multirow[t]{2}{*}{$\begin{array}{l}\text { Energy } \\
\text { Efficiency } \\
\text { Standard }\end{array}$} & \multirow[t]{2}{*}{$\begin{array}{c}\text { Heat Pump } \\
\text { Type }\end{array}$} & $\begin{array}{c}\text { Final Energy } \\
\text { Consumption } \\
\text { for Heating, } \\
Q_{\mathrm{F}, \mathrm{H}}\end{array}$ & $\begin{array}{c}\text { Final Energy } \\
\text { Consumption } \\
\text { for DHW, } \\
\text { Q }_{\mathrm{F}, \mathrm{DHW}}\end{array}$ & $\begin{array}{c}\text { Final Energy } \\
\text { Consumption } \\
\text { Auxiliary } \\
\text { Systems }\end{array}$ & $\begin{array}{c}\text { Final Energy } \\
\text { Consumption } \\
\text { Ventilation } \\
\text { Unit } \\
\end{array}$ & $\begin{array}{c}\text { Total Final } \\
\text { Energy } \\
\text { Consumption, } \\
Q_{F}\end{array}$ \\
\hline & & kWh/year & kWh/year & kWh/year & kWh/year & kWh/year \\
\hline WT2021 & \multirow[b]{2}{*}{ ASHP } & 4450 & 2827 & 503 & - & 7827 \\
\hline NF40 & & 1665 & 2842 & 400 & 296 & 5203 \\
\hline WT2021 & \multirow{3}{*}{ GSHP } & 3570 & 2842 & 503 & - & 6915 \\
\hline NF40 & & 1313 & 2780 & 400 & 296 & 4788 \\
\hline NF15 & & 441 & 2780 & 284 & 296 & 3801 \\
\hline
\end{tabular}

Results clearly showed that in the case of buildings with high energy efficiency (NF40 and NF15) the energy consumption for water heating was more significant than for heating. Energy used by auxiliary systems decreased with the increase of building standard because the heating season became shorter. At the same time use of mechanical ventilation caused additional energy consumption.

In order to reach the plus energy standard, the amount of energy produced on-site had to be higher than total final energy consumption over the course of a year. For each variant PV panels were used and installed on the south roof surface. The available roof area was limited to $35 \mathrm{~m}^{2}$. In order to maximize the energy production monocrystalline panels were selected in the case of WT2021. They are more effective but also more expensive. The amount of energy produced was calculated on basis of SOLEKO data [36]. The results of the selection can be seen in Table 12.

Table 12. Selection of photovoltaic panels for the WT2021, NF40 and NF15 standards.

\begin{tabular}{|c|c|c|c|c|c|c|}
\hline \multirow{2}{*}{$\begin{array}{c}\text { Energy } \\
\text { Efficiency } \\
\text { Standard }\end{array}$} & \multirow{2}{*}{$\begin{array}{l}\text { Heat Pump } \\
\text { Type }\end{array}$} & $\begin{array}{l}\text { Total Final Energy } \\
\text { Consumption, } Q_{F}\end{array}$ & $\begin{array}{l}\text { Peak Load of } \\
\text { PV System }\end{array}$ & $\begin{array}{l}\text { Estimated Electrical } \\
\text { Energy Production }\end{array}$ & $\begin{array}{l}\text { Area of the } \\
\text { PV Panels }\end{array}$ & $\begin{array}{l}\text { Number of } \\
\text { PV Panels }\end{array}$ \\
\hline & & $\mathrm{kWh} /$ year & $\mathbf{k W p}$ & kWh/year & $\mathrm{m}^{2}$ & - \\
\hline WT2021 & \multirow{3}{*}{ ASHP } & 7827 & 6.30 & 6600 & 34 & 20 \\
\hline NF40 & & 5203 & 5.13 & 5400 & 31 & 18 \\
\hline NF15 & & 3982 & 3.99 & 4200 & 24 & 14 \\
\hline WT2021 & \multirow{3}{*}{ GSHP } & 6915 & 6.30 & 6600 & 34 & 20 \\
\hline NF40 & & 4788 & 4.56 & 4800 & 28 & 16 \\
\hline NF15 & & 3801 & 3.99 & 4200 & 24 & 14 \\
\hline
\end{tabular}

In the case of WT2021 it was impossible to reach plus energy level, despite the use of more efficient panels. The limited roof area and high energy consumption were the main barriers. The assembly of panels on the external walls was not considered due to their lower efficiency and the risk of shading. 
The next step of the analysis was the calculation of investment and exploitation costs also for the WT2021 standard. Based on results presented in Table 10 the final energy consumption and production indexes were calculated (Table 13). On their basis possible requirements for a plus energy single family building were proposed.

Table 13. Final energy indexes for the WT2021, NF40 and NF15 standards.

\begin{tabular}{|c|c|c|c|}
\hline \multirow{2}{*}{$\begin{array}{l}\text { Energy Efficiency } \\
\text { Standard }\end{array}$} & \multirow[t]{2}{*}{ Heat Pump Type } & $\begin{array}{c}\text { Index of Final Energy } \\
\text { Consumption }\end{array}$ & $\begin{array}{l}\text { Index of Electrical } \\
\text { Energy Production }\end{array}$ \\
\hline & & $\mathrm{kWh} /\left(\mathrm{m}^{2}\right.$ year $)$ & $\mathrm{kWh} /\left(\mathrm{m}^{2}\right.$ year $)$ \\
\hline WT2021 & \multirow{3}{*}{ ASHP } & 60.7 & 51.2 \\
\hline NF40 & & 40.3 & 41.9 \\
\hline NF15 & & 30.9 & 32.6 \\
\hline WT2021 & \multirow{3}{*}{ GSHP } & 53.6 & 51.2 \\
\hline NF40 & & 37.1 & 37.2 \\
\hline NF15 & & 29.5 & 32.6 \\
\hline
\end{tabular}

\section{Costs Calculation}

The WT2021 standard was adopted as the reference. The calculation was made separately for the building envelope and the systems. For the building envelope the cost increased in the case of NF40 and NF15 standards, because of thicker insulation layer, better windows, thermal bridges reduction and increase of air-tightness. System costs included heat pump (and vertical exchanger if required), $\mathrm{PV}$ panels and mechanical ventilation.

\subsection{Construction Costs}

The summary of the additional construction costs resulting from the insulation of building elements is presented in Table 14.

Table 14. Additional cost of insulation for the NF40 and NF15 standards.

\begin{tabular}{|c|c|c|c|c|c|}
\hline \multirow[t]{2}{*}{ Building Element/Insulation Material } & $\begin{array}{c}\text { Reference } \\
\text { Thickness of } \\
\text { the Insulation } \\
\text { WT2021 }\end{array}$ & $\begin{array}{l}\text { Additional } \\
\text { Layer on } \\
\text { Insulation } \\
\text { NF40 }\end{array}$ & $\begin{array}{l}\text { Additional } \\
\text { Layer on } \\
\text { Insulation } \\
\text { NF15 }\end{array}$ & $\begin{array}{l}\text { Additional } \\
\text { Cost of } \\
\text { Insulation } \\
\text { NF40 }\end{array}$ & $\begin{array}{l}\text { Additional } \\
\text { Cost of } \\
\text { Insulation } \\
\text { NF40 }\end{array}$ \\
\hline & $\mathrm{cm}$ & $\mathrm{cm}$ & $\mathrm{cm}$ & EUR & EUR \\
\hline External walls/styrofoam & 20 & +1 & +15 & 71 & 967 \\
\hline Floor on ground/mineral wool & 10 & +6 & +20 & 192 & 518 \\
\hline Floor under unheated attic/mineral wool & 30 & +5 & +10 & 111 & 222 \\
\hline Flat roof/mineral wool & 30 & +5 & +10 & 25 & 51 \\
\hline Roof/mineral wool & 30 & +8 & +16 & 376 & 693 \\
\hline \multicolumn{4}{|c|}{ Total cost } & 775 & 2451 \\
\hline
\end{tabular}

It was necessary to replace external doors and windows so that they met the requirements of specific NF15 standard. Because there is only small difference between WT2021 and NF40 standard no change in the cost was assumed. The prices of doors and windows 34re based on the online calculator [37]. The cost summary is presented in the Table 15.

Table 15. Additional cost of external windows and doors for the NF40 and NF15 standards.

\begin{tabular}{cccccc}
\hline \multirow{2}{*}{ Building Rlement } & $\begin{array}{c}\text { Reference Thickness } \\
\text { U-value WT2021 }\end{array}$ & $\begin{array}{c}\text { U-value } \\
\mathbf{N F 4 0}\end{array}$ & $\begin{array}{c}\text { U-value } \\
\mathbf{N F 1 5}\end{array}$ & $\begin{array}{c}\text { Additional } \\
\text { Cost NF40 }\end{array}$ & $\begin{array}{c}\text { Additional } \\
\text { Cost NF40 }\end{array}$ \\
\cline { 2 - 6 } & $\mathbf{W} /\left(\mathbf{m}^{\mathbf{2}} \cdot \mathbf{K}\right)$ & $\mathbf{W} /\left(\mathbf{m}^{2} \cdot \mathbf{K}\right)$ & $\mathbf{W} /\left(\mathbf{m}^{2} \cdot \mathbf{K}\right)$ & EUR & EUR \\
\hline External doors & 0.90 & 1.0 & 0.80 & 0 & 186 \\
External windows & 1.30 & 1.30 & 0.80 & 0 & 373 \\
& Total cost & & & $\mathbf{0}$ & $\mathbf{5 5 9}$ \\
\hline
\end{tabular}


Another increase in construction costs resulted from the need to limit heat losses through thermal bridges. These costs included, e.g., the installation of window frames in the insulation layer in the NF15 standard. In addition, it was necessary to increase the air-tightness of the building envelope. Based on our own research [38-40], it was assumed that both improvements will cost 815 EUR in the NF40 and 1500 EUR in the NF15.

The use of balanced ventilation with heat recovery saved on the cost of building a chimney. In relation to the WT2021 standard with natural ventilation, this saving amounted to 580 EUR for the variant NF40 and NF15. The summary of all construction cost is presented in Figure 3. The minus values represent the savings. In total the costs increased by 1010 EUR for NF40 and by 3930 EUR for NF15 in regard to WT2021.

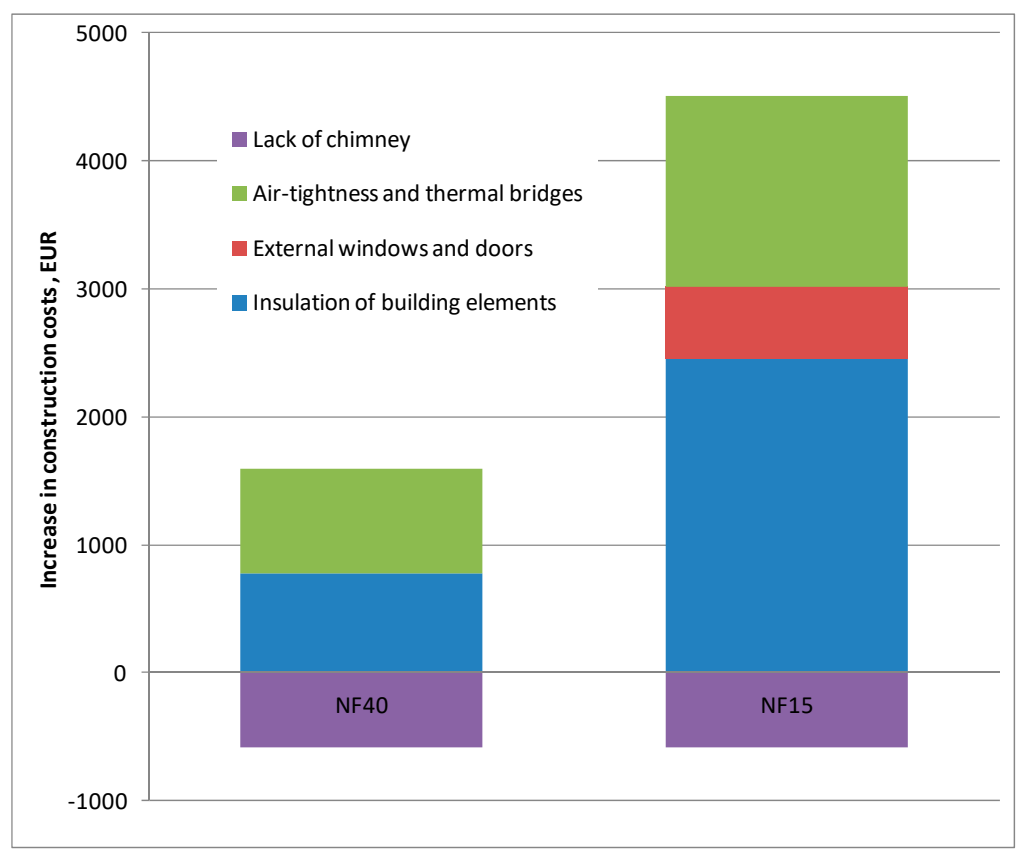

Figure 3. The increase in construction costs for the standards NF40 and NF15.

\subsection{Systems Costs}

The cost of the photovoltaic system included the cost of solar panels, inverter, additional elements like cables and installation. Depending on peak power and panels type the costs were estimated based on the price list of SOLEKO company [36]. Installation of a solar panel on a roof covered with standard roofing tiles was 35 EUR for each photovoltaic panel. The total cost for each building variant is presented in Table 16.

Table 16. The photovoltaic system cost.

\begin{tabular}{cccccccc}
\hline $\begin{array}{c}\text { Energy } \\
\text { Efficiency } \\
\text { Standard }\end{array}$ & $\begin{array}{c}\text { Heat } \\
\text { Pump } \\
\text { Type }\end{array}$ & $\begin{array}{c}\text { Peak Load of } \\
\text { PV System }\end{array}$ & $\begin{array}{c}\text { Number of } \\
\text { PV Panels }\end{array}$ & $\begin{array}{c}\text { Inverter } \\
\text { Cost }\end{array}$ & $\begin{array}{c}\text { PV Panels and } \\
\text { Equipment Cost }\end{array}$ & $\begin{array}{c}\text { Installation } \\
\text { Cost }\end{array}$ & $\begin{array}{c}\text { Total } \\
\text { Cost }\end{array}$ \\
\hline WT2021 & & 6.30 & - & EUR & - & EUR & EUR \\
NF40 & ASHP & 5.13 & 20 & 1510 & 5350 & 700 & 7560 \\
NF15 & & 3.99 & 14 & 1479 & 4101 & 630 & 6210 \\
\hline WT2021 & & 6.30 & 20 & 1260 & 3390 & 490 & 5140 \\
NF40 & GSHP & 4.56 & 16 & 1310 & 5350 & 700 & 7560 \\
NF15 & & 3.99 & 14 & 1260 & 3720 & 560 & 5670 \\
\hline
\end{tabular}

The cost of the heating and DHW system included the cost of heat pump, hot water tank, control module, additional equipment, vertical exchanger (if required), installation and commissioning. 
Depending on the heating load and pump type the costs were estimated based on the price list of NIBE company $[29,31]$. The vertical exchanger cost was calculated based on assumed maximum feat flow of $45 \mathrm{~W}$ per one meter of the boreholes and the cost of 25 EUR for each meter of the drilling [31]. The total cost for each building variant is presented in Table 17. As expected, the cost depended on the heating load and the type of heat pump. The ASHPs were almost twice as cheap as GSHPs because there was no need for the vertical exchanger.

Table 17. The heating and DHW system cost.

\begin{tabular}{|c|c|c|c|c|c|c|c|}
\hline \multirow{2}{*}{$\begin{array}{l}\text { Energy } \\
\text { Efficiency } \\
\text { Standard }\end{array}$} & \multirow{2}{*}{$\begin{array}{l}\text { Heat } \\
\text { Pump } \\
\text { Type }\end{array}$} & \multirow{2}{*}{$\begin{array}{l}\text { Heat Pump } \\
\text { Model }\end{array}$} & $\begin{array}{l}\text { Heat Pump } \\
\text { Cost }\end{array}$ & $\begin{array}{l}\text { Equipment } \\
\text { Cost }\end{array}$ & $\begin{array}{c}\text { Vertical } \\
\text { Exchanger Cost }\end{array}$ & $\begin{array}{l}\text { Installation } \\
\text { Cost }\end{array}$ & Total Cost \\
\hline & & & EUR & EUR & EUR & EUR & EUR \\
\hline \multirow{2}{*}{$\begin{array}{c}\text { WT2021 } \\
\text { NF40 } \\
\text { NF15 }\end{array}$} & \multirow[b]{2}{*}{ ASHP } & $\mathrm{F} 204012 \mathrm{~kW}$ & 7150 & 1840 & - & 535 & 9525 \\
\hline & & F2040 6 kW & 4860 & 1840 & - & 535 & 7235 \\
\hline \multirow{2}{*}{$\begin{array}{c}\text { WT2021 } \\
\text { NF40 } \\
\text { NF15 }\end{array}$} & \multirow[b]{2}{*}{ GSHP } & $\mathrm{F} 122612 \mathrm{~kW}$ & 8730 & 1750 & 6670 & 720 & 17,870 \\
\hline & & F1226 6 kW & 7440 & 1750 & 3330 & 720 & 13,240 \\
\hline
\end{tabular}

Selection of smaller heat pumps (if an appropriate type would be available) in the case of NF15 standard would have little influence on its price. In the case of the air source heat pump from Daikin the difference in price between $4.3 \mathrm{~kW}$ and $6.0 \mathrm{~kW}$ was lower than $10 \%$. The difference in price between $5.7 \mathrm{~kW}$ and $7.6 \mathrm{~kW}$ for Vitocal 333-G of Viessmann was 5\%.

The last element of the building systems was in case of NF40 and NF15 the balance ventilation with heat recovery. The cost was calculated on a basis of an offer from PRO-VENT [41] company. It included installation of ventilation ducts, ventilation unit with heat recovery, regulation and commissioning of the entire system. NF40 and NF15 standards use the same type of ventilation unit, therefore the cost of EUR 5325 for both variants is identical. The summary of all system costs for all standards is shown in Figure 4.

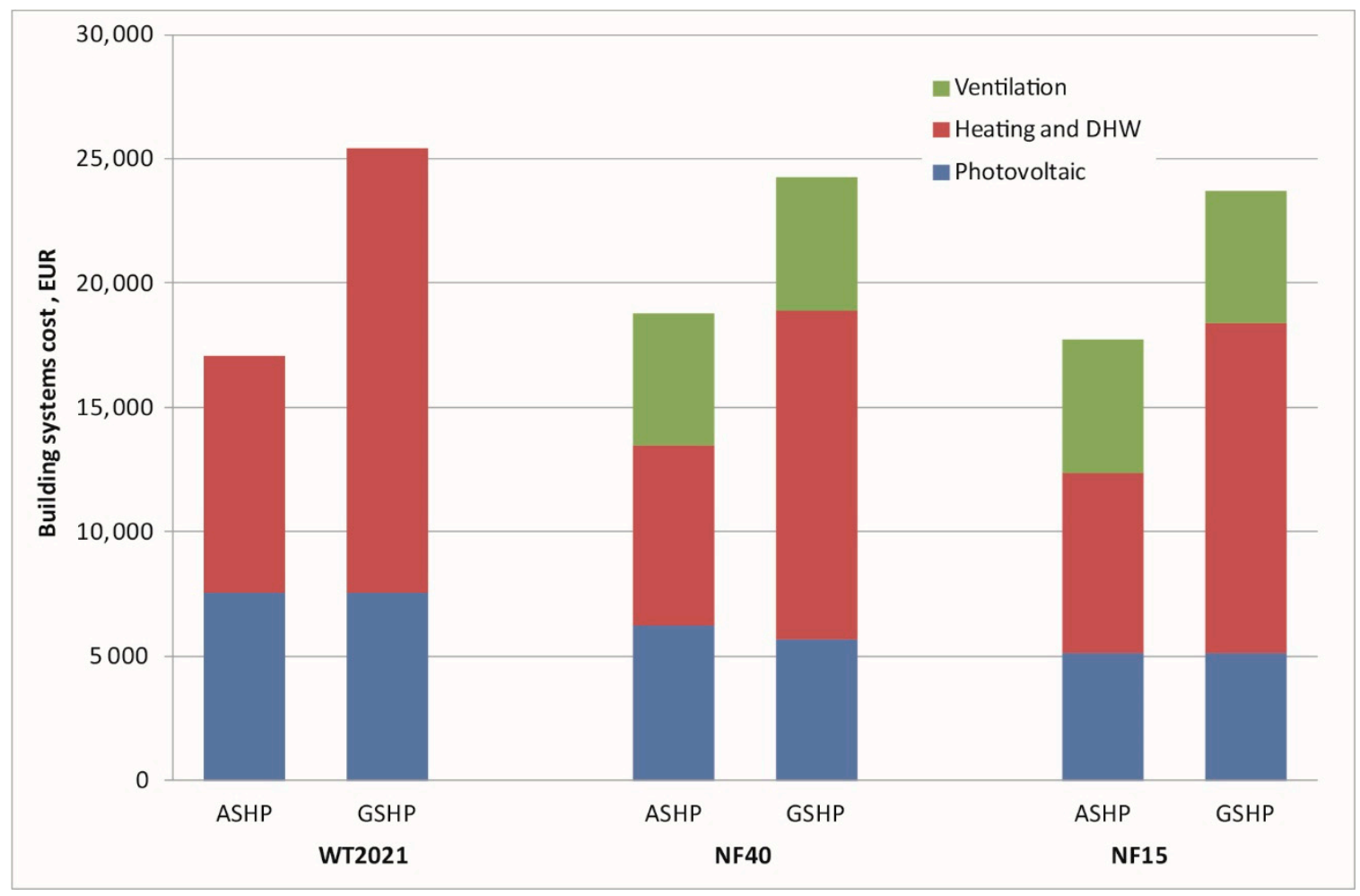

Figure 4. The building systems cost for all the variants. 
The total systems cost did not change much with the change of the building energy efficiency standard. Although the heat source capacity can be smaller the additional cost of balanced ventilation appeared. Higher differences could be seen in regard to the heat pump type. Use of ASHP reduced the costs from $23 \%$ to $33 \%$. A full assessment of investment costs was possible after adding extra construction costs (Figure 5).

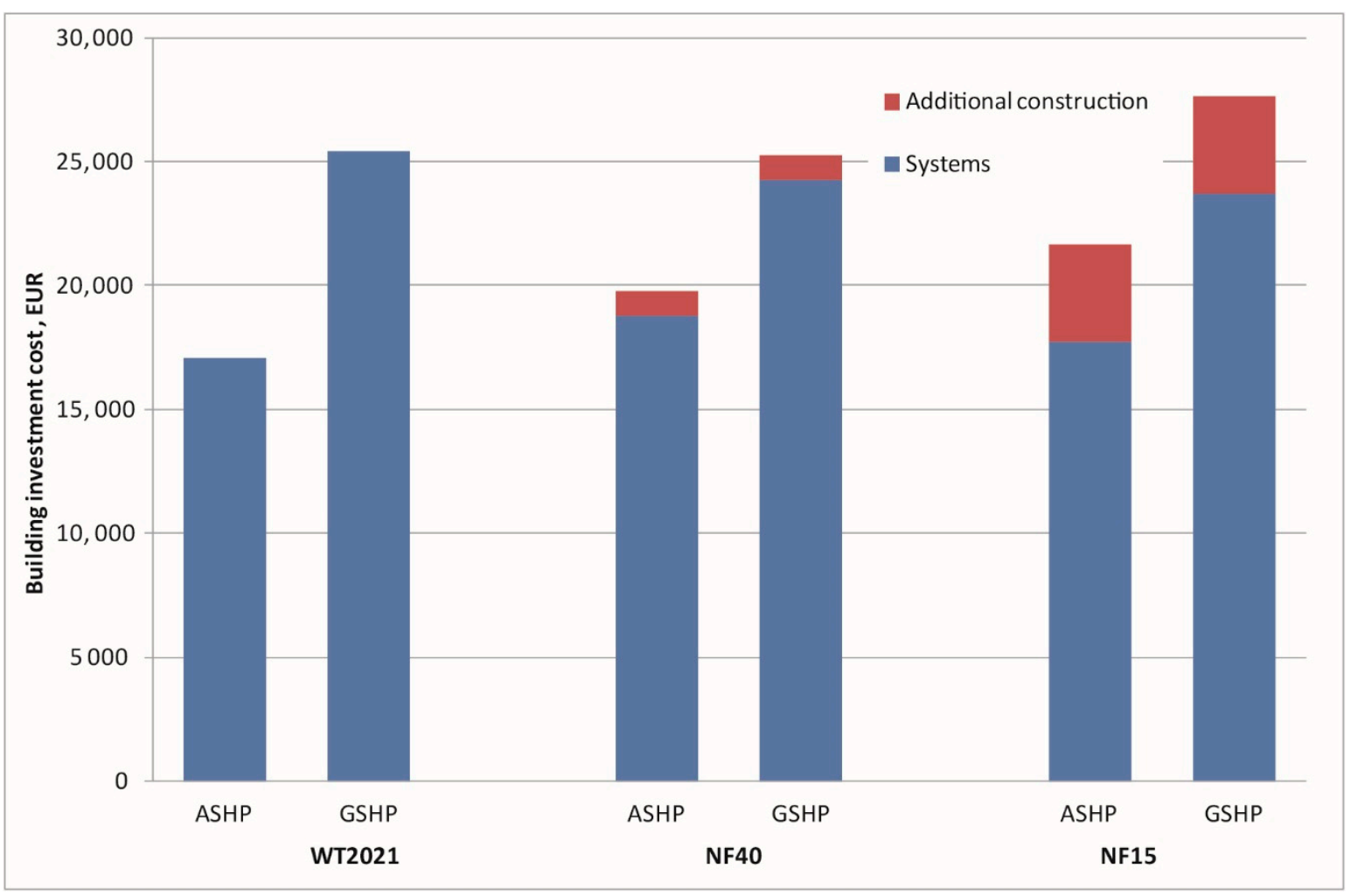

Figure 5. The investment cost for all the variants.

Reaching the plus energy standard would be cheapest in case of WT2021 with the ASHP but the amount of energy produced by the PV panels was too small (lower than consumption). Because of that, the NF40 standard with air source heat pump represented the lowest investment cost. Changing to GSHP increased the cost by about $28 \%$ and to NF15 by about $9 \%$. The share of additional construction cost was minor because the system cost dominates.

\subsection{Replacement and Maintenance Costs}

The analysis included the replacement costs of system components during the explanation of the building. It was a periodic cost corresponding to the lifespan of the component. The used lifetime expectancies are shown in Table 18 and based on standard EN 15459-1 [16]. The calculation concentrated mainly on the energy systems of the house. Final value of system components at the end of calculation period was given as a percentage of replacement cost. For example, in a case of heat pumps they would have to be replaced in year 30 which was at the same time calculation period. Therefore, the final value was in this case $100 \%$.

The annual maintenance costs were calculated as percentage of the investment costs related to the system component based on standard EN 15459-1 [16]. For the photovoltaic system and vertical exchanger it was $1 \%$ while for heat pumps and balanced ventilation $2 \%$. The operation cost was calculated on a basis of final energy consumption of auxiliary systems and the ventilation unit. 
Table 18. Replacement cost and lifespan of building systems.

\begin{tabular}{|c|c|c|c|c|c|c|c|}
\hline \multirow[t]{2}{*}{ System Component } & $\begin{array}{l}\text { Investment } \\
\quad \text { Cost }\end{array}$ & $\begin{array}{l}\text { Lifespan } 5 \\
\quad \text { Years }\end{array}$ & $\begin{array}{l}\text { Lifespan } \\
10 \text { Years }\end{array}$ & $\begin{array}{l}\text { Lifespan } \\
15 \text { Years }\end{array}$ & $\begin{array}{l}\text { Lifespan } \\
20 \text { Years }\end{array}$ & $\begin{array}{l}\text { Lifespan } \\
25 \text { Years }\end{array}$ & $\begin{array}{l}\text { Lifespan } \\
30 \text { Years }\end{array}$ \\
\hline & EUR & EUR & EUR & EUR & EUR & EUR & EUR \\
\hline PV system 6.3 kWp & 7560 & & & & 7560 & & \\
\hline PV system $5.13 \mathrm{kWp}$ & 6210 & & & & 6210 & & \\
\hline PV system $4.56 \mathrm{kWp}$ & 5670 & & & & 5670 & & \\
\hline PV system $3.99 \mathrm{kWp}$ & 4140 & & & & 4140 & & \\
\hline ASHP F2040 12 kW & 9525 & & & 9525 & & & 9525 \\
\hline ASHP F2040 6 kW & 7235 & & & 7235 & & & 7235 \\
\hline GSHP F1226 12 kW & 11,200 & & & 11,200 & & & 11,200 \\
\hline GSHPF1226 6 kW & 9910 & & & 9910 & & & 9910 \\
\hline Vertical exchanger $12 \mathrm{~kW}$ & 6670 & & & & & & 6670 \\
\hline Vertical exchanger $6 \mathrm{~kW}$ & 3330 & & & & & & 3330 \\
\hline Balance ventilation & 5325 & & & & 5325 & & \\
\hline \multicolumn{2}{|c|}{$\begin{array}{l}\text { Final value of the component at the end } \\
\text { of period- } 30 \text { years }\end{array}$} & & & $0 \%$ & $50 \%$ & & $100 \%$ \\
\hline
\end{tabular}

\subsection{Annual Costs Related to Energy Consumption}

Annuals costs related to energy consumption included heating, DHW and systems operation. Theoretically they should have been zero because the house was designed at plus energy standard. In reality only part of the energy produced by PV panels would be used on site. According to measurements made in Poland [42] around 25\% of the consumption is covered by the solar electrical energy. The rest has to be supplied to the grid in the case of buildings without energy storage. Owners of solar power plants with a capacity of up to $10 \mathrm{kWp}$ for each $1 \mathrm{kWh}$ delivered to the grid can get back $0.8 \mathrm{kWh}$ for free, which results from Polish regulations [43]. Such a solution was included in the analysis and was the basis for calculations of electrical energy send back to the grid and used from the grid. The price of $1 \mathrm{kWh}$ was 0.15 EUR. Precise data for each variant are presented in Table 19.

Table 19. Calculation of annual cost related to the energy used from the electrical grid.

\begin{tabular}{|c|c|c|c|c|c|c|c|}
\hline \multirow[t]{2}{*}{$\begin{array}{l}\text { Energy } \\
\text { Efficiency } \\
\text { Standard }\end{array}$} & \multirow[t]{2}{*}{$\begin{array}{c}\text { Heat } \\
\text { Pump } \\
\text { Type }\end{array}$} & $\begin{array}{c}\text { Total Final } \\
\text { Energy } \\
\text { Consumption } \\
Q_{\mathrm{F}}\end{array}$ & $\begin{array}{c}\text { Estimated } \\
\text { Electrical } \\
\text { Energy } \\
\text { Production PV }\end{array}$ & $\begin{array}{l}\text { Estimated } \\
\text { On-Site } \\
\text { Consumption }\end{array}$ & $\begin{array}{l}\text { Energy } \\
\text { Sent Back } \\
\text { to the } \\
\text { Grid }\end{array}$ & $\begin{array}{l}\text { Paid } \\
\text { Energy } \\
\text { from the } \\
\text { Grid }\end{array}$ & $\begin{array}{l}\text { Annual Cost } \\
\text { Related to } \\
\text { Energy Used } \\
\text { from the Grid }\end{array}$ \\
\hline & & kWh/year & kWh/year & kWh/year & kWh/year & kWh/year & EUR/year \\
\hline WT2021 & \multirow{3}{*}{ ASHP } & 7827 & 6600 & 1957 & 4643 & 2156 & 323 \\
\hline NF40 & & 5203 & 5400 & 1301 & 4099 & 623 & 93 \\
\hline NF15 & & 3982 & 4200 & 996 & 3205 & 423 & 63 \\
\hline WT2021 & \multirow{3}{*}{ GSHP } & 6915 & 6600 & 1729 & 4871 & 1289 & 193 \\
\hline NF40 & & 4788 & 4800 & 1197 & 3603 & 709 & 106 \\
\hline NF15 & & 3801 & 4200 & 950 & 3250 & 251 & 38 \\
\hline
\end{tabular}

Results showed that even for variants that met the plus energy standard (NF40 and NF15) annual cost related to energy consumption was higher than zero. It was actually the cost of storing the produced electrical energy in the grid.

\subsection{Global Cost Calculation}

For all the house and system variants the global cost was calculated. It was a sum of the present value of all annual costs (with reference to starting year) including investment costs. The annual costs included systems replacement and maintenance, as well as energy consumption. Final value of component or system at the end of the calculation period was considered in the analysis. The following financial data were used:

- duration of the calculation: 30 years

- inflation rate: $2 \%$ 
- $\quad$ real interest rate: $3 \%$

- evolution of energy prices: $2 \%$ (electricity).

The values were based on the data from Polish Office of Competition and Consumer Protection [44] constant during the analysed period. Results of global cost calculation for all variants were shown in Table 20 and in Figure 6.

Table 20. Calculation of annual cost related to the energy used from the electrical grid.

\begin{tabular}{|c|c|c|c|c|c|c|c|c|}
\hline \multirow{3}{*}{ Costs } & \multirow{3}{*}{ Type } & \multirow{2}{*}{$\begin{array}{c}\text { Present } \\
\text { Value Factor }\end{array}$} & \multicolumn{2}{|c|}{ WT2021 } & \multicolumn{2}{|c|}{ NF40 } & \multicolumn{2}{|c|}{ NF15 } \\
\hline & & & ASHP & GSHP & ASHP & GSHP & ASHP & GSHP \\
\hline & & - & EUR & EUR & EUR & EUR & EUR & EUR \\
\hline \multirow{5}{*}{ Investment } & \multirow{5}{*}{$\begin{array}{c}\text { PV } \\
\text { heat pump } \\
\text { vertical exchanger } \\
\text { balanced } \\
\text { ventilation } \\
\text { construction }\end{array}$} & 1.0 & 7560 & 7560 & 6210 & 5670 & 5140 & 5140 \\
\hline & & 1.0 & 9525 & 11,200 & 7235 & 9910 & 7235 & 9910 \\
\hline & & 1.0 & & 6670 & & 3330 & & 3330 \\
\hline & & 1.0 & & & 5325 & 5325 & 5325 & 5325 \\
\hline & & 1.0 & & & 1010 & 1010 & 3930 & 3930 \\
\hline \multirow{4}{*}{ Replacement } & lifespan 15 years & 0.864 & 9525 & 11,200 & 7235 & 9910 & 7235 & 9910 \\
\hline & lifespan 20 years & 0.823 & 7560 & 7560 & 11,535 & 10,995 & 10,465 & 10,465 \\
\hline & lifespan 30 years & 0.746 & 9525 & 17,870 & 7235 & 13,240 & 7235 & 13,240 \\
\hline & final value & 0.746 & 13,305 & 21,650 & 13,003 & 18,738 & 12,468 & 18,473 \\
\hline Maintenance & all systems & $25.882 *$ & 266 & 366 & 313 & 395 & 303 & 389 \\
\hline \multirow[t]{2}{*}{ Energy } & all systems & $25.882 *$ & 323 & 193 & 93 & 106 & 63 & 38 \\
\hline & Global cost & & 43,959 & 52,980 & 41,732 & 51,708 & 42,048 & 51,963 \\
\hline
\end{tabular}

* in a case of Maintenance and Energy sum of present value factors for the whole calculation period was presented in Table 20.

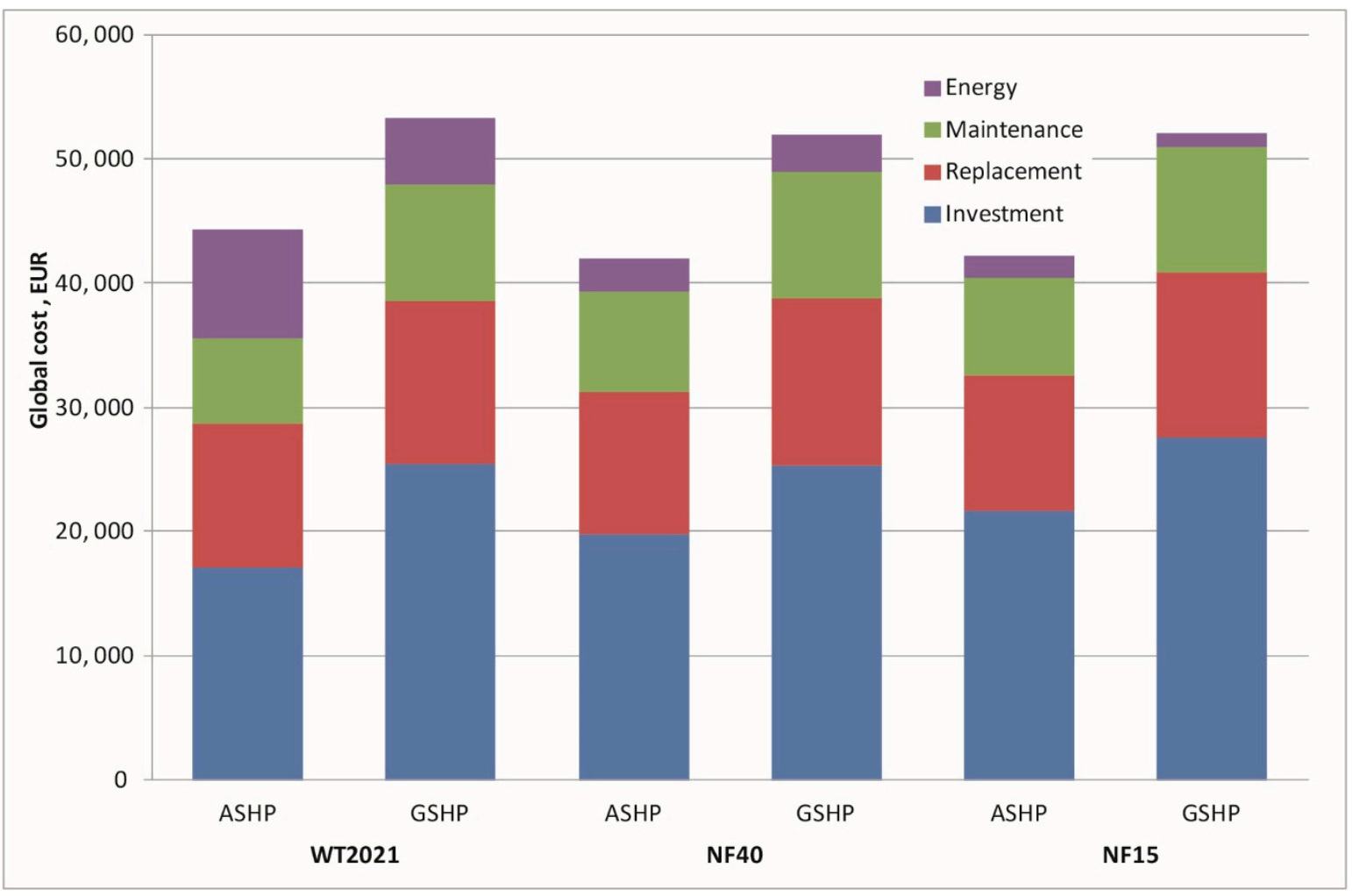

Figure 6. The global cost for all variants. 


\section{Results and Discussion}

After analysing all six variants differing in thermal insulation of building elements, the solution of the ventilation system and technical systems, it was possible to assess them from the point of view of economic viability. The global cost values obtained proved that the NF40 (41,732 EUR) and NF15 (42,048 EUR) variants using the air source heat pump were the most favourable. The difference between them was lower than $1 \%$. Another option with a relatively low global cost was a building in the WT2021 standard also with ASHP (global cost higher by 5\% in regard to NF40 ASHP). It should be noted, however, that it did not meet the plus energy building criterion. A ground source heat pump with vertical exchanger turned out to be more expensive in each variant. The reason is mainly higher investment costs associated with the need of the heat exchanger (global cost higher by $24 \%-27 \%$ depending on the variant). Investing more money in a higher energy efficiency standard-NF15, proved not entirely justified. Low demand for energy and heating load does not significantly affect the cost of systems. The selected heat pumps were oversized, because in the catalogues of the supplier company no smaller devices were available. From this perspective cost of heating system is the same in case of NF40 and NF15. Also, the cost of PV systems is only slightly different from the cost for the NF40 standard.

Increase of energy efficiency of house had visible influence on energy cost in the calculation period. Meeting the plus energy standard caused the share of energy costs in global costs to range from $6 \%-5 \%$ for NF40 to $4 \%-2 \%$ for NF15. In the case of WT2021 it was from $19 \%$ to $9 \%$. The replacement and maintenance cost played very important roles in the global cost. Depending on the variant it was between $42 \%$ and $47 \%$. It clearly showed that energy systems of the buildings are becoming more important that its energy efficiency. Correct selection of them is crucial from the economic and energy efficiency point of view. Investment costs had the smallest share in case of WT2021 variant.

\section{Conclusions}

The main objective of this paper was to propose possible requirements for plus energy building definition in the heating dominated climate of central Poland. The question was what is more cost-effective: reduction of energy demand or increase of production from renewable energy sources. The obtained analysis allowed the formulation of the following conclusions:

- It can be definitely stated that the economic sense of using renewable heat sources leaves no doubt, bearing in mind that the efficiency of these devices increases year by year (thanks to new solutions [45]), what causes higher profitability of this type of system. Moreover, the low-energy standards NF40 and NF15 allow for achieving the plus energy level in cold climate of central Poland, which was proved by the study.

- The research has shown that reaching the plus energy standard will be not possible in the case of WT2021-houses meeting only specific requirements of the building code for year 2021. The high energy consumption cannot be covered by on-site energy production.

- The global cost of the plus energy house (in standard NF40 and NF15) depended mainly on the system type (ASHP or GSHP) and only slightly on energy consumption. The maintenance, replacement and investment cost related with the energy systems had the biggest share in global cost. It clearly showed that proper selection and dimensioning of the systems is the key to plus energy standard. From the economic point of view the use of ASHP seemed to be more effective despite lower efficiency in a cold climate. Another important issue was the storage and utilization of energy produced on site [46].

- In the analysed model of the house the available roof area was limited to $35 \mathrm{~m}^{2}$. Similar limitation will occur in the majority of single-family buildings in Poland. By referring the maximum energy production to the heated area-6600 $\mathrm{kWh} /$ year to $129 \mathrm{~m}^{2}$ a coefficient of $51.2 \mathrm{kWh} /\left(\mathrm{m}^{2}\right.$ year) can be calculated. To reach a plus energy standard final energy consumption (Table 13), for heating, ventilation, DHW and auxiliary systems, has to lower than this coefficient. The final energy 
consumption index was $40.3 \mathrm{kWh} /\left(\mathrm{m}^{2}\right.$ year) for NF40-ASHP, $30.9 \mathrm{kWh} /\left(\mathrm{m}^{2}\right.$ year) for NF15-ASHP, $37.1 \mathrm{kWh} /\left(\mathrm{m}^{2}\right.$ year) for NF40-GSHP and $29.5 \mathrm{kWh} /\left(\mathrm{m}^{2}\right.$ year $)$ for NF15-ASHP. In each case it was lower than maximum energy production coefficient.

The formulated conclusions can be used as a basis for proposing possible requirements for plus energy building standards in central Poland. From the three different energy types-energy need, final energy and primary energy, the final energy taking into consideration the efficiencies of the systems seemed to be most suitable. The potential indicators of the definition should be the index of final (delivered) energy demand $\mathrm{Q}_{\mathrm{F}}$ and the index of on-site energy production $\mathrm{Q}_{\mathrm{F}, \mathrm{P}}$. Based on research the proposed requirements for plus energy single-family residential buildings are as follows:

- The final (delivered) energy demand (including heating, ventilation, DHW and auxiliary systems) $\mathrm{Q}_{\mathrm{F}}<45 \mathrm{kWh} /\left(\mathrm{m}^{2}\right.$ year $)$; and

- $\quad$ The on-site energy production $\mathrm{Q}_{\mathrm{F}, \mathrm{P}}>45 \mathrm{kWh} /\left(\mathrm{m}^{2}\right.$ year $)$.

The proposed values are in the middle between maximum energy production and maximum energy consumption. Both requirements should refer to the electrical energy and not to the heat.

Funding: This research was funded by Warsaw University of Technology, Faculty of Civil Engineering as part of statutory work.

Acknowledgments: I gratefully thank Wioleta Krupa for the technical support.

Conflicts of Interest: The author declares no conflict of interest.

\section{References}

1. EPBD. Directive 2010/31/EU of the European Parliament and of Council of 19 May 2010 on the energy performance of buildings (recast). Off. J. Eur. Union 2010, 153, 13-35.

2. The revised EPBD: Directive (EU) 2018/844 of the European Parliament and of the Council of 30 May 2018 amending Directive 2010/31/EU on the energy performance of buildings and Directive 2012/27/EU on energy efficiency. Off. J. Eur. Union 2018, 156, 75-91.

3. Ministry of Infrastructure and Development Poland. Uniform Text of the Regulation of the Minister of Infrastructure on the Technical Conditions to be Met by Buildings and Their Location; OJ 2015 Item 1422; Ministry of Infrastructure and Development Poland: Warsaw, Poland, 2015.

4. Firlag, S. How to meet the minimum energy performance requirements of Technical Conditions in year 2021? Procedia Eng. 2015, 111, 202-208. [CrossRef]

5. Król, P.; Firlag, S.; Węglarz, A. Integrated environmental impact assessment of single-family houses. Rynek Instalacyjny 2013, 9, 20-25.

6. Firlag, S.; Piasecki, M. NZEB renovation definition in a heating dominated climate: Case study of Poland. Appl. Sci. 2018, 8, 1605. [CrossRef]

7. Ballarini, I.; De Luca, G.; Paragamyan, A.; Pellegrino, A.; Corrado, V. Transformation of an office building into a nearly Zero Energy Building (nZEB): Implications for thermal and visual comfort and energy performance. Energies 2019, 12, 895. [CrossRef]

8. Gustafsson, M.S.; Myhren, J.A.; Dotzauer, E.; Gustafsson, M. Life cycle cost of building energy renovation measures, considering future energy production scenarios. Energies 2019, 12, 2719. [CrossRef]

9. Ramírez-Villegas, R.; Eriksson, O.; Olofsson, T. Combined environmental and economic assessment of energy efficiency measures in a multi-dwelling building. Energies 2019, 12, 2484. [CrossRef]

10. Slonski, M.; Schrag, T. Linear optimisation of a settlement towards the energy-plus house standard. Energies 2019, 12, 210. [CrossRef]

11. Choi, W.J.; Joo, H.J.; Park, J.-W.; Kim, S.-K.; Lee, J.-B. Power generation performance of building-integrated photovoltaic systems in a Zero Energy Building. Energies 2019, 12, 2471. [CrossRef] 
12. Bundesministerium des Innern, für Bau und Heimat. Wege Zum Effizienzhaus Plus Grundlagen Und Beispiele Für Energieerzeugende Gebäude. 2018. Available online: https://www.bmi.bund.de/SharedDocs/downloads/DE/publikationen/themen/bauen/effizienzhausplus.pdf;jsessionid=2A6AF8BDB44256C1D1FF25F9F71914B9.2_cid295?_blob=publicationFile\&v=6 (accessed on 2 August 2019).

13. Energieagentur Regio Freiburg, Das Sonnenschiff, 1Das sonnenschIff, Dienstleistungszentrum mit innovativem Energiekonzept Ein ökologisches Modell für die Zukunft. 2009. Available online: http://www. rolfdisch.de/wp-content/uploads/BROSCHU\%CC\%88RE_DAS_SONNENSCHIFF_DBU.pdf (accessed on 2 August 2019).

14. Melgar, S.G.; Bohórquez, M.Á.M.; Márquez, J.M.A. uhuMEB: Design, construction, and management methodology of minimum energy buildings in subtropical climates. Energies 2018, 11, 2745. [CrossRef]

15. Data for Energy Calculations of Buildings, Ministry of Investment and Development, Poland. Available online: https://www.gov.pl/web/inwestycje-rozwoj/dane-do-obliczen-energetycznych-budynkow (accessed on 2 August 2019).

16. Energy Performance of Buildings-Economic Evaluation Procedure for Energy Systems in Buildings-Part 1: Calculation Procedures; EN 15459-1; CEN: Brussels, Belgium, 2007; Available online: http://www.cres.gr/ greenbuilding/PDF/prend/set4/WI_29_TC-approval_version_prEN_15459_Data_requirements.pdf (accessed on 2 August 2019).

17. Ferrara, M.; Fabrizio, E.; Virgone, J.; Filippi, M. A simulation-based optimization method for cost-optimal analysis of nearly Zero Energy Buildings. Energy Build. 2014, 84, 442-457. [CrossRef]

18. Hamdy, M.; Hasan, A.; Siren, K. A multi-stage optimization method for cost-optimal and nearly-zero-energy building solutions in line with the EPBD-recast 2010. Energy Build. 2013, 56, 189-203. [CrossRef]

19. National Fund for Environmental Protection and Water Management, Priority Program-Effective Use of Energy. Subsidies for Loans for the Construction of Energy-Efficient Houses. Available online: https: //www.nfosigw.gov.pl/download/gfx/nfosigw/pl/nfoopisy/791/3/5/pp_domy_05.12.2015.pdf (accessed on 2 August 2019).

20. Xu, S.; Ma, G.; Liu, Q.; Liu, Z. Experiment study of an enhanced vapor injection refrigeration/heat pump system using R32. Int. J. Therm. Sci. 2013, 68, 103-109. [CrossRef]

21. Carnieletto, L.; Badenes, B.; Belliardi, M.; Bernardi, A.; Graci, S.; Emmi, G.; Urchueguía, J.F.; Zarrella, A.; di Bella, A.; Dalla, G.; et al. A European Database of Building Energy Profiles to Support the Design of Ground Source Heat Pumps. Energies 2019, 12, 2496. [CrossRef]

22. Javed, S.; Ørnes, I.R.; Myrup, M.; Dokka, T.H. Design optimization of the borehole system for a plus-Energy kindergarten in Oslo. Archit. Eng. Des. Manag. 2019, 15, 181-195. [CrossRef]

23. ORT PC, The Heat Pump Market in Poland in 2010-2018 Prospects for the Development of the Heat Pump Market Until 2030, Kraków. 2019. Available online: http://portpc.pl/pdf/raporty/Raport_PORTPC_wersja_ final_2019.pdf (accessed on 2 August 2019).

24. Miara, M.; Günther, D.; Langner, R. Efficiency of heat pump systems under real operating conditions. IEA Heat Pump Cent. Newsl. 2013, 2, 22-26.

25. Krupa, W. Adaptation of a Single-Family Building Project to the Almost Zero-Energy Standard. BSc Engineering Thesis, Warsaw University of Technology, Warszawa, Poland, 2019. Available online: http://repo.bg.pw.edu.pl/index.php/pl/r\#/info/bachelor/WUT2bb8b03283124e42a1a6e8a2504c9e1b/ ?r=diploma\&tab=\&lang=pl (accessed on 2 August 2019).

26. Energy Performance of Buildings_Calculation of Energy Use for Space Heating and Cooling; ISO 13790:2008; International Organization for Standardization: Geneva, Switzerland, 2008; Available online: https://www. iso.org/standard/41974.html (accessed on 2 August 2019).

27. Energy Performance of Buildings. Method for Calculation of the Design Heat Load. Space Heating Load, Module M3-3; EN 12831-1: 2017; CEN: Brussels, Belgium, 2017; Available online: https://shop.bsigroup.com/ProductDetail/ ?pid=000000000030309933 (accessed on 2 August 2019).

28. Ministry of Infrastructure and Development Poland. Regulation of the Minister of Infrastructure and Development of 27 February 2015 on the Methodology for Determining the Energy Performance of a Building or Part of a Building and Energy Performance Certificates; OJ 2015 Item 376; Ministry of Infrastructure and Development Poland: Warsaw, Poland, 2015. Available online: http://prawo.sejm.gov.pl/isap.nsf/DocDetails.xsp?id=WDU20150000376 (accessed on 2 August 2019). 
29. NIBE. Available online: https://www.nibe.pl/Produkty/Powietrzne-pompy-ciepla-przeglad/NIBE-F2040/ (accessed on 2 August 2019).

30. Piechurski, K.; Szulgowska-Zgrzywa, M. Impact of climate conditions and building design heating load on the energy efficiency of air source heat pumps. Rynek Instalacyjny. 2016, 10. Available online: https:/www.viessmann.edu.pl/wp-content/uploads/Zalacznik_artykul_Efektywnosc_ PC_powietrze_woda.pdf (accessed on 2 August 2019).

31. NIBE. Available online: https://www.nibe.pl/Produkty/Gruntowe-pompy-ciepla-przeglad/NIBE-F1226/ (accessed on 2 August 2019).

32. Ventilation for Buildings. Calculation of Room Temperatures and of Load and Energy for Buildings with Room Conditioning Systems; EN 15243:2007; CEN: Brussels, Belgium, 2007; Available online: http://store.uni.com/catalogo/index.php/en-15243-2007.html?josso_back_to=http://store.uni.com/ josso-security-check.php\&josso_cmd=login_optional\&josso_partnerapp_host=store.uni.com (accessed on 2 August 2019).

33. Heating Systems in Buildings. Method for Calculation of System Energy Requirements and System Efficiencies; EN 15316:2007; CEN: Brussels, Belgium, 2007; Available online: http://www.cres.gr/greenbuilding/PDF/prend/ set1/WI_08_TC-approval_version_prEN_15316-2-1_Space_heating_emission_systems.pdf (accessed on 2 August 2019).

34. Heating Systems in Buildings-Method for Calculation of System Energy Requirements and System Efficiencies-Part 3-1: Domestic Hot Water Systems, Characterisation of Needs; EN 15316-3-1:2005; CEN: Brussels, Belgium, 2005; Available online: http://www.cres.gr/greenbuilding/PDF/prend/set3/WI_11_TC-approval_version_prEN_ 15316-3-1_Domestic_hot_water-Characterization_of_needs.pdf (accessed on 2 August 2019).

35. European Parliament. Commission Delegated Regulation (EU) No 811/2013 of 18 February 2013 supplementing Directive 2010/30/EU of the European Parliament and of the Council with regard to the energy labelling of space heaters, combination heaters, packages of space heater, temperature control and solar device and packages of combination heater, temperature control and solar device. Off. J. Eur. Union 2013, L239. Available online: https://eur-lex.europa.eu/legal-content/EN/TXT/?uri=CELEX\%3A32013R0811 (accessed on 2 August 2019).

36. SOLEKO. Available online: https://www.kolektory.com/instalacje-fotowoltaiczne-ceny/instalacjefotowoltaiczne-ceny.html (accessed on 2 August 2019).

37. BESTOKNA.PL. Available online: https://bestokna.pl/kalkulator (accessed on 2 August 2019).

38. Firlag, S.; Miszczuk, A. Air tightness of low-energy buildings in the context of building services. Rynek Instalacyjny 2015, 4, 56-62.

39. Firlag, S. Air tightness of passive and energy-saving buildings-test results. Czas. Tech. 2012, 3, 105-113.

40. Anysz, H.; Narloch, P. Designing the composition of cement stabilized rammed earth using artificial neural networks. Materials 2019, 12, 1396. [CrossRef]

41. Pro-Vent. Available online: https://www.pro-vent.pl/ (accessed on 2 August 2019).

42. Wnuk, R. RES Technologies in Deep Thermal Renovation of Buildings, Forum Termomodernizacja Conference, Warsaw. 2019. Available online: https://zae.org.pl/wp-content/uploads/2019/04/5.-Ryszard-Wnuk_KAPEForum_Termomodernizacji_v3.pdf (accessed on 2 August 2019).

43. Journal of Laws, Item 478 Act on Renewable Energy Sources. Polish Parliament Office. 20 February 2015. Available online: http://prawo.sejm.gov.pl/isap.nsf/download.xsp/WDU20150000478/U/D20150478Lj.pdf (accessed on 2 August 2019).

44. Office of Competition and Consumer Protection. Available online: https://www.uokik.gov.pl/stopa referencyjna_i_archiwum.php (accessed on 2 August 2019).

45. Conti, P.; Schito, E.; Testi, D. Cost-Benefit analysis of hybrid photovoltaic/thermal collectors in a nearly zero-energy building. Energies 2019, 12, 1582. [CrossRef]

46. Węglarz, A.; Pierzchalski, M.; Dariusz Heim, D. Peripheral Isothermal System of Heat Gain Storage for Thermal Stability in Low-Energy Buildings. Appl. Sci. 2019, 9, 3091. [CrossRef]

(C) 2019 by the author. Licensee MDPI, Basel, Switzerland. This article is an open access article distributed under the terms and conditions of the Creative Commons Attribution (CC BY) license (http://creativecommons.org/licenses/by/4.0/). 